\title{
Physicochemical characterization and evaluation of PGA bioflocculant in coagulation-flocculation and sedimentation processes
}

\author{
Valquíria Campos*, Ana R.A.C. Fernandes, Thales. A.M. Medeiros, Erik L. Andrade \\ Instituto de Ciência e Tecnologia de Sorocaba, Univ. Estadual Paulista, UNESP, Brazil
}

\section{A R T I C L E I N F O}

\section{Article history:}

Received 11 May 2016

Received in revised form 12 July 2016

Accepted 11 August 2016

Available online 12 August 2016

\section{Keywords:}

PGA bioflocculant

Polyaluminum chloride

Aluminum sulfate

Salto de pirapora WTP

São paulo

\begin{abstract}
A B S T R A C T
This paper analyzesanalyses the effectiveness of three commercial products: aluminum sulfate, aluminum polychloride and polyglutamic acid-based bioflocculant, in water clarification and purification. Poly- $\gamma$-glutamic acid (PGA), a naturally occurring anionic polymer, is already produced on an industrial scale. A conventional jar test apparatus was used for flocculation experiments. The tests were performed using raw water from the Salto de Pirapora Water Treatment Plant (WTP) in the state of São Paulo, Brazil. The structure and elemental composition of PGA bioflocculant, which was characterized by Fourier transform infrared spectroscopy (FTIR), scanning electron microscopy (SEM), X-ray diffraction (XRD), X-ray fluorescence spectrometry (XRF) and thermogravimetric analysis (TGA), suggests that it is basically inorganic in nature, with high contents of calcium sulfate (87\%) and $\gamma$-polyglutamic acid (5\%), among other chemical compounds. The performance of PGA bioflocculant was superior to that of the other coagulants. In the dry season, $80 \mathrm{mg} \mathrm{L}^{-1}$ of PG $\alpha 21 \mathrm{Ca}$ removed $89.74 \%$ of apparent color, and residual turbidity was 5.78 NTU. In the rainy season, $90 \mathrm{mg} \mathrm{L}^{-1}$ of PG $\alpha 21 \mathrm{Ca}$ removed $96.89 \%$ of apparent color and residual turbidity was 1.93 NTU.
\end{abstract}

(c) 2016 Elsevier Ltd. All rights reserved.

\section{Introduction}

Conventional water treatment methods include coagulation, flocculation and sedimentation processes, usually followed by filtration and disinfection. Coagulation-flocculation is considered the most important process in surface water treatment, and it can be used as a pre-treatment, post-treatment, or even main treatment [1]. The main parameters used in the physical characterization of natural water are color, turbidity, the various fractions of solids levels, temperature, taste and odor. Although these are physical parameters, they provide valuable preliminary information to characterize the chemical quality of water, e.g., suspended solids levels (associated with turbidity) and concentrations of dissolved solids (associated with color), organic solids (volatile) and mineral solids (fixed), which are the compounds that produce odor, among other things.

The purpose of removing or reducing turbidity is to increase the efficiency of chlorination to disinfect water. In a water treatment plant (WTP) that uses the complete water cycle treatment, a decrease in process efficiency and in rapid-mix, flocculation and sedimentation operations causes clogging of the filters, which thus

\footnotetext{
* Corresponding author.

E-mail address: vcampos@sorocaba.unesp.br (V. Campos).
}

require more frequent washing, and may lead to increased turbidity and less effective disinfection of the water supply. Hence, the parameters of rapid-mix, flocculation and sedimentation markedly influence the overall removal efficiency of impurities contained in raw water. Therefore, these parameters should not be simply adopted, but established based on laboratory studies or a pilot plant. The coagulation-flocculation process also enables the identification of potential products that can be used as coagulants for water treatment, some of which are readily available, such as aluminum and iron-based coagulants, while others are experimental coagulants, such as PGA bioflocculant. According to the literature, the performance of each coagulant may also vary, depending on the type of water to be treated.

Coagulants are used extensively in the treatment of public water supply systems. The two most widely used coagulants are aluminum and iron salts [2]. Aluminum sulfate was commonly used in Brazil because of its low cost and high efficiency in the treatment of public water supply. However, aluminum is not biodegradable and high concentrations of this metal are harmful to health, possibly even aggravating disorders such as Alzheimer's disease $[3,4]$. Currently, WTPs use prepolymerized aluminum salt, known as polyaluminum chloride (PAC). Due to its basicity, PAC generally releases less acid than other coagulants during hydrolysis, causing little variation in the $\mathrm{pH}$ level of treated water. For this 
reason, media coagulated by PAC require little or no use of $\mathrm{pH}$ adjustment products. In addition to requiring only very slight $\mathrm{pH}$ adjustment, PAC is efficient in destabilizing particles, thus favoring the rapid formation of large uniform flakes without the need for flocculating aids. Although aluminum sulfate and PAC present favorable characteristics as inorganic coagulants, chemical formulations containing aluminum reportedly have harmful effects [5] and commonly produce a large amount of hazardous sludge containing residual metals [6]. Thus, there is a great demand for the development of a coagulant that poses no risk to the environment or to human health. To this end, numerous polymer matrices have been proposed for the removal of contaminants from water and for the treatment of wastewater. Biodegradable flocculants could represent an alternative to the conventional flocculants currently in use. Reports are available on the application of bioflocculants such as chitosan, which may be used for both coagulation and flocculation [1,7]. Sellami et al. [8] evaluated cactus juice as a bioflocculant in the coagulationflocculation process for industrial wastewater treatment. Campos et al. $[9,10]$ polymerized bentonites to obtain ionene derivatives, combining polysoap properties with organophilic properties for possible application in the removal of organic pollutants.

Poly- $\gamma$-glutamic acid (PGA) is commercially available as PG $\alpha 21 \mathrm{Ca}$, a powder containing $14 \%$ of poly- $\gamma$-glutamic acid, which is stabilized with minerals such as calcium sulfate [11]. The biopolymer $\gamma$-polyglutamic acid ( $\gamma$-PGA) is anionic, water-soluble, biodegradable, biocompatible, edible and non-toxic to humans and the environment. Due to these special characteristics, it has been applied in the environmental sector as a coagulant agent. Several researchers have described the use of $\gamma$-PGA in water treatment [12-15]. Shih and Van [16] stated that poly-g-glutamic acid is a polyamide flocculant and it is considered the best option because of its high yield, high flocculating activity and ability to flocculate a wide range of organic and inorganic compounds.

The purpose of this study was to evaluate the efficiency of commercial coagulants based on coagulation, flocculation and sedimentation tests. Experimental series were performed using traditional products such as aluminum sulfate, polyaluminum chloride and polyglutamic acid-based PGA bioflocculant, a Japanese product described as effective in the decontamination of water for human consumption. Another aim of this study is to understand the behavior and physicochemical stability of PG $\alpha 21$ a.

\section{Material and methods}

The bioflocculant PG $\alpha 21 \mathrm{Ca}^{\mathrm{TM}}$ from Nippon Poly-Glu Co. Ltd. was supplied in powder form, with a recommendation for the use of $0.05-0.1 \mathrm{~g} \mathrm{~L}^{-1}$. The product's typical flocculation time is $15 \mathrm{~min}$ at an initial turbidity of 100 NTU, resulting in a final turbidity of $<1$ NTU. The aluminum sulfate and aluminum chloride were supplied by the Salto de Pirapora WTP.

Raw water was collected from the Salto de Pirapora WTP, because of its importance for the metropolitan area of Sorocaba. The sample was digested with concentrated nitric acid and heated to $100^{\circ} \mathrm{C}$ in a block digester to determine the cations in the raw water, using inductively coupled plasma optical emission spectroscopy (ICP-OES, Spectro Arcos) in radial-view mode. The chromatographic method (HPLC/IC model 430) was used for the simultaneous determination of anions.

The PG $\alpha 21$ Ca was characterized to determine its chemical composition, thermal stability, and morphology by means of X-ray fluorescence spectrometry (XRF), X-ray diffraction (XRD), elemental analysis, infrared spectroscopy, thermal analysis and scanning electron microscopy. Before subjecting the PG $\alpha 21 \mathrm{Ca}$ to physicochemical characterization, it was sifted through a stainless steel sieve (Tyler, $200 \mathrm{mesh}$ ) with $0.075 \mathrm{~mm}$ sieve opening size, placed in stoppered flasks, and stored in a desiccator.

The PG $\alpha 21 \mathrm{Ca}$ was analyzed by energy dispersive X-ray fluorescence (EDXRF) using a PANalytical Epsilon 3 spectrometer.

Basal spacings were determined by X-ray diffraction (XRD) in a Rigaku MiniFlex diffractometer, using $\mathrm{CuK} \alpha$ radiation $(\lambda=0.15416 \mathrm{~nm})$ and a scintillation detector at $30 \mathrm{kV}$ and $15 \mathrm{~mA}$ at a rotation of $5-80^{\circ}$ at a scale of $2 \theta$, applying $0.02^{\circ}$ steps at $0.6 \mathrm{~s} / \mathrm{step}$. The data were analyzed using Diffraction Plus software, integrated with JCPDS - International Center for Diffraction Data (ICDD) version 2001.

The purpose of the elemental analysis was to identify elements commonly found in organic compounds, such as carbon, hydrogen and nitrogen, and was performed in a Perkin Elmer $2400 \mathrm{CHN}$ elemental analyzer. The elemental analysis was performed in duplicate.

The infrared spectrum of absorption was obtained by means of Fourier transform infrared spectroscopy (FTIR), using a Perkin Elmer Frontier FTIR spectrometer.

The PG $\alpha 21 \mathrm{Ca}$ was thermally analyzed in the temperature range of $10-1000{ }^{\circ} \mathrm{C}$, applying a heating rate of $20^{\circ} \mathrm{C} \mathrm{min}^{-1}$. The samples were degraded in a TA Instruments 50 thermogravimetric analyzer (TGA 50) in an air oxidizing atmosphere and nitrogen atmosphere, using a nitrogen flow of $50 \mathrm{~cm}^{3} \mathrm{~min}^{-1}$ and a synthetic air flow of $100 \mathrm{~mL} \mathrm{~min}^{-1}$. A sample of about $12 \mathrm{mg}$ was used in all the experiments.

Structural information about PG $\alpha 21$ Ca was obtained using a conventional scanning electron microscope (SEM). The micrograph was magnified by up to $5000 \mathrm{X}$ after coating the surface of the sample with $\mathrm{Au}$. The analysis was performed using a scanning electron microscope (LEO 440i) coupled to an energy dispersive $\mathrm{X}$-Ray spectrometer (EDS) (Oxford Si (Li) detector).

\section{Results and discussion}

\subsection{Physicochemical characterization of $P G \alpha 21 \mathrm{Ca}$}

The specific surface area $\left(\mathrm{S}_{\mathrm{BET}}\right)$ of $\mathrm{PG} \alpha 21 \mathrm{Ca}$ was determined by the Brunauer- Emmet-Teller (BET) method through physical adsorption of $\mathrm{N}_{2}$ at low temperatures, using measurements in the relative pressure range $\left(\mathrm{P} / \mathrm{P}_{0}\right)$ of $0.05-0.1$. The pore volume was calculated by the Barrett-Joyner-Halenda (BJH) method [17] and by means of the $\mathrm{N}_{2}$ adsorption isotherm. PG $\alpha 21 \mathrm{Ca}$ was found to have a specific surface area of $1799 \mathrm{~m}^{2} \mathrm{~g}^{-1}$ and a pore volume of $0.004 \mathrm{~cm}^{3} \mathrm{~g}^{-1}$.

The physicochemical analysis of PG $\alpha 21$ Ca was performed via EDXRF, which revealed the percentage of oxides in the commercial product (Table 1 ). The results were normalized and expressed as $\mathrm{Na}$ and $\mathrm{U}$ oxides, excluding light elements such as $\mathrm{H}, \mathrm{He}, \mathrm{Li}, \mathrm{Be}, \mathrm{B}, \mathrm{C}$, $\mathrm{N}, \mathrm{O}, \mathrm{F}$, and $\mathrm{Ne}$.

The elemental analysis of PG $\alpha 21$ Ca indicated $\mathrm{CHN}$ percentages in the composition of the commercial product, which are listed in Table 2. According to Ho et al. [18], an elemental analysis of $\gamma$-polyglutamic acid typically shows $44.86 \%(\mathrm{C}), 5.91 \%(\mathrm{H})$ and $10.49 \%(\mathrm{~N})$, which is consistent with the composition calculated here as $46.51 \%(\mathrm{C}), 5.43 \%(\mathrm{H})$ and $10.85 \%(\mathrm{~N})$. The $\gamma$-polyglutamic acid content in $\mathrm{PG} \alpha 21 \mathrm{Ca}$ was estimated considering that the formula of $\gamma$-polyglutamic acid is $\left(\mathrm{C}_{5} \mathrm{H}_{7} \mathrm{NO}_{3}\right)_{\mathrm{n}}$, while that based only on the monomer is $46.51 \%(\mathrm{C}), 5.46 \%(\mathrm{H}), 10.84 \%(\mathrm{~N})$ and $37.17 \%$ (O). However, it is prudent to deduce the $\gamma$-PGA content from the

Table 1

Chemical composition of PG $\alpha 21 \mathrm{Ca}$ analyzed by X-ray fluorescence (in mass\%).

\begin{tabular}{lllllllllll}
\hline Sample & $\mathrm{SiO}_{2}$ & $\mathrm{Al}_{2} \mathrm{O}_{3}$ & $\mathrm{SO}_{3}$ & $\mathrm{MgO}$ & $\mathrm{CaO}$ & $\mathrm{Na}_{2} \mathrm{O}$ & $\mathrm{K}_{2} \mathrm{O}$ & $\mathrm{Cl}_{2} \mathrm{O}$ & $\mathrm{Fe}_{2} \mathrm{O}_{3}$ & $\mathrm{TiO}_{2}$ \\
\hline PG $\alpha 21 \mathrm{Ca}$ & 6.63 & 2.97 & 47.33 & 0.49 & 40.41 & 0.09 & 0.13 & 0.99 & 0.71 & 0.05 \\
\hline
\end{tabular}


Table 2

CHN content of PG $\alpha 21 \mathrm{Ca}$. .

\begin{tabular}{lllll}
\hline Sample & $C / \%$ & $H / \%$ & $N / \%$ & $C H N_{\text {Total }}$ \\
\hline PG $\alpha 21 \mathrm{Ca}$ & 2.45 & 2.53 & 0.04 & 5.02 \\
\hline
\end{tabular}

carbon analysis, based on the assumption that this element is present only in $\gamma$-PGA, since hydrogen may be present in other salts or as hydration water and the nitrogen content was negligible. Owing to this low $\gamma$-PGA content in the sample, the nitrogen results were not considered sufficiently reliable to deduce its content by the analytical combustion technique used here. In this case, considering the carbon content in $\gamma$-PGA, the commercial product contained $5.26 \%$.

\subsection{X-ray diffraction}

The mineralogical composition of the sample was determined qualitatively based on an X-ray diffraction analysis. The XRD analysis showed peaks characteristic of gypsum $\mathrm{CaSO}_{4} \cdot 2 \mathrm{H}_{2} \mathrm{O}$ and anhydrite $\mathrm{Ca}\left(\mathrm{SO}_{4}\right)$. The identified compounds are summarized in Fig. 1 and Table 3. No mineralogical species typical of silicates were found, but the chemical analysis revealed silicon, which may be present as amorphous silica.

\section{3. $P G \alpha 21$ Ca morphology}

The microstructure of the sample was examined by SEM. To this end, the powder sample was spread on an adhesive, double-stick carbon tape which was then pressed onto a 0.5 inch diameter stub. Various areas of the sample spread on the stub were examined, and after ensuring that its morphology and morphometry did not vary, images were recorded by a secondary electron detector.

The SEM micrographs revealed morphologies typical of gypsite (Fig. 2). The mineral appeared in the form of thick platelets ranging in size from 10 to $30 \mu \mathrm{m}$, and at another moment, as aggregates of up to $30 \mu \mathrm{m}$ in size, composed of particles of approximately one micron. The representativeness of the sample can be shown in other micrographs. Chemical mapping of its composition by EDS revealed the presence of $\mathrm{Ca}, \mathrm{S}, \mathrm{Si}$ and $\mathrm{Al}$.
Table 3

Interlayer spacing $d_{h k l}$ on dried basis ( $\left.\mathrm{nm}\right)$.

\begin{tabular}{llll}
\hline PG $\alpha 21 \mathrm{Ca}$ & $d / \mathrm{I}$ & $d / \mathrm{I}$ & $d / \mathrm{I}$ \\
\hline Gypsum & $0.426 / 100$ & $0.755 / 88.21$ & $0.266 / 36.27$ \\
Anhydrite & $0.349 / 100$ & $0.285 / 60.16$ & $0.220 / 38.88$ \\
\hline
\end{tabular}

Note: d-spacing and I-intensity.

\subsection{Infrared spectroscopy}

The FTIR-ATR technique was used to identify the typical chemical groups of $\gamma$-PGA in PG $\alpha 21 \mathrm{Ca}$, by means of the characteristic bands. The infrared spectra were obtained from FTIR grade potassium bromide pellets in the range of 4000$400 \mathrm{~cm}^{-1}$ for observation of the functional groups (Fig. 3).

The FTIR analysis of PG $\alpha 21 \mathrm{Ca}$ in Fig. 3 shows vibrations characteristic of hydroxyl groups at a wavelength of $3400 \mathrm{~cm}^{-1}$, as well as vibrations in the range of $900 \mathrm{~cm}^{-1}$ corresponding to the Al$\mathrm{OH}_{2}$ group. Standing out between the bands characteristic of aluminum sulfate are $\nu_{1}$ at around $990 \mathrm{~cm}^{-1}, \nu_{3}$ at around $1113-$ $1089 \mathrm{~cm}^{-1}$ and $\nu_{4}$ at around $620-553 \mathrm{~cm}^{-1}[19]$.

The position of the 3392 and $3495 \mathrm{~cm}^{-1}$ bands in some gypsum infrared spectra may occur close to 3400 and $3540 \mathrm{~cm}^{-1}$ [20]. One of the four vibrational modes of $\mathrm{SO}_{4}{ }^{2-}$ was observed in the spectrum of the PG $\alpha 21 \mathrm{Ca}$ sample, in the $v_{3} \mathrm{SO}_{4}$ stretching mode, which occurs at around $1120 \mathrm{~cm}^{-1}$ for gypsum [21]. The gypsum showed two bands at 1685 and $1620 \mathrm{~cm}^{-1}$, which were attributed to the presence of two types of water molecules. The band at $1685 \mathrm{~cm}^{-1}$ is characteristic of weak molecular bonds, while the band at $1620 \mathrm{~cm}^{-1}$ is characteristic of strong molecular bonds [21]. The PG $\alpha 21$ a spectrum showed bands characteristic of gypsum at $3400 \mathrm{~cm}^{-1}$. The gypsum also presented three absorption bands in the stretching region of the $\mathrm{OH}$ group $\left(\nu_{\mathrm{OH}}\right)$ at 3245,3392 and $3495 \mathrm{~cm}^{-1}$ [20].

The FTIR analysis also revealed vibration bands characteristic of $\gamma$-PGA at wavelengths of 1620,1113 and $675 \mathrm{~cm}^{-1}$. Ho et al. [18] described the FTIR absorption for calcium $\gamma$-polyglutamate in $\mathrm{KBr}$ pellets as: Amide I, N-H bending band at $1622 \mathrm{~cm}^{-1}$; Amide II, stretching band not observed presumably due to strong ionic complexation; $\mathrm{C}=\mathrm{O}$ symmetric stretching band at $1412 \mathrm{~cm}^{-1}$;

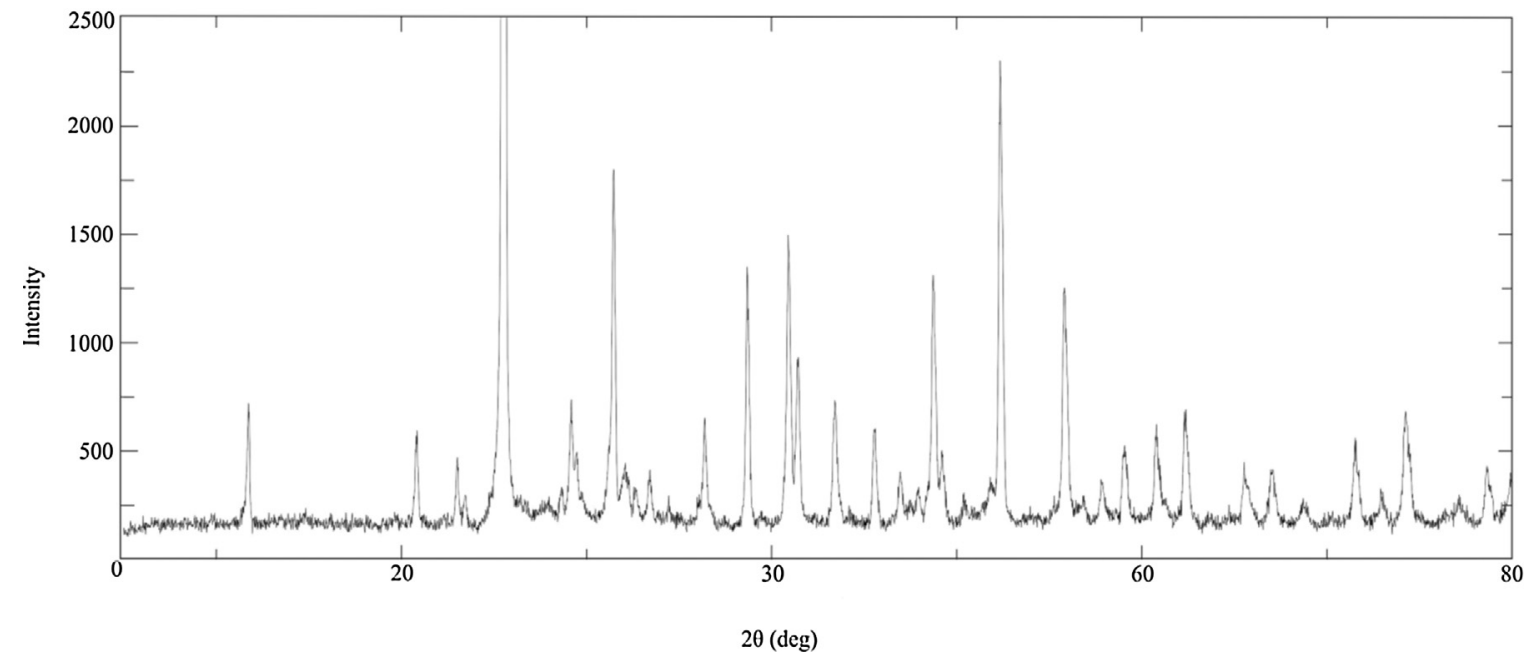

Fig. 1. X-ray diffractogram of PG $\alpha 21$ Ca. 

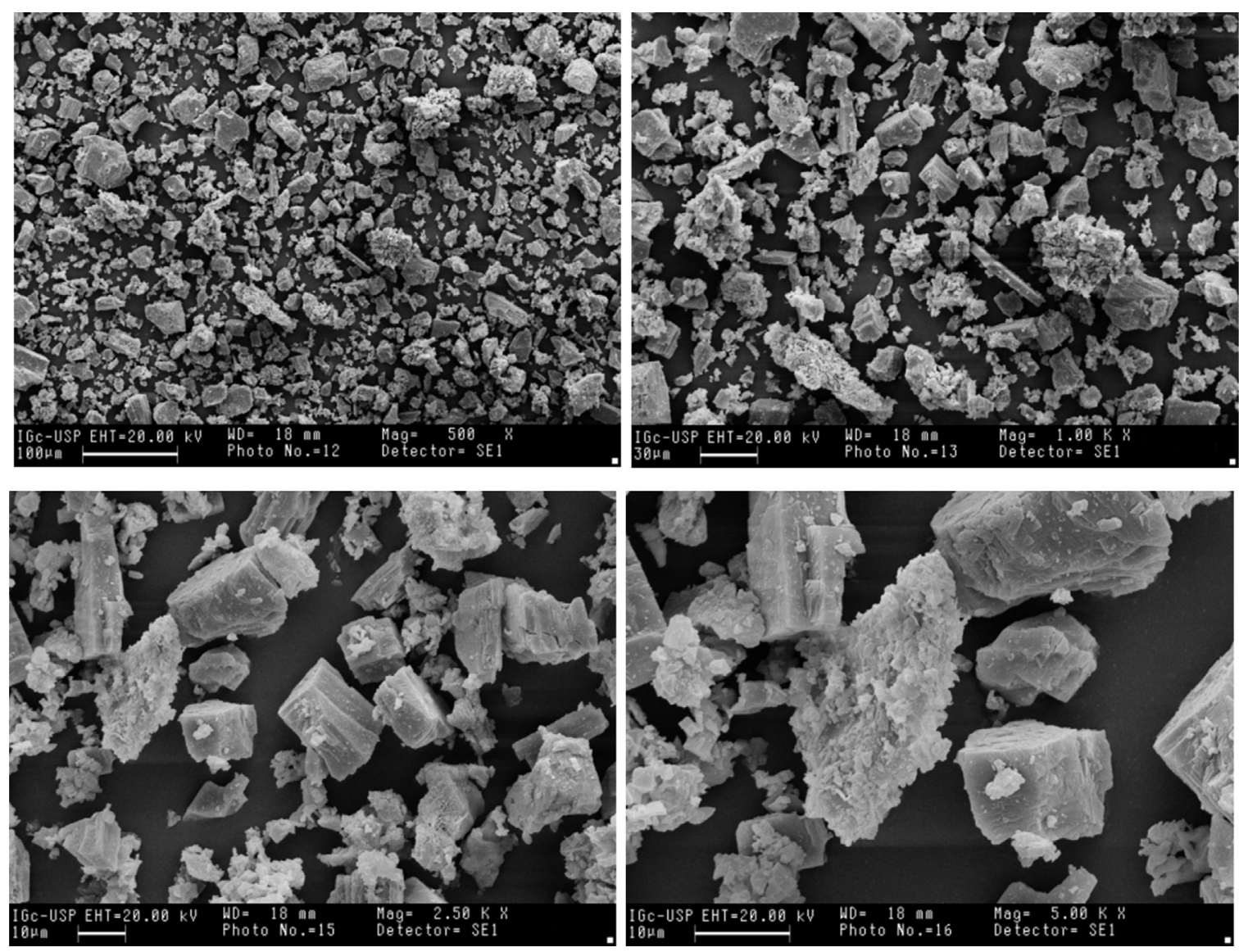

Fig. 2. SEM images of PG $\alpha 21 \mathrm{Ca}(500,1000,2500$ and 5000X magnification).

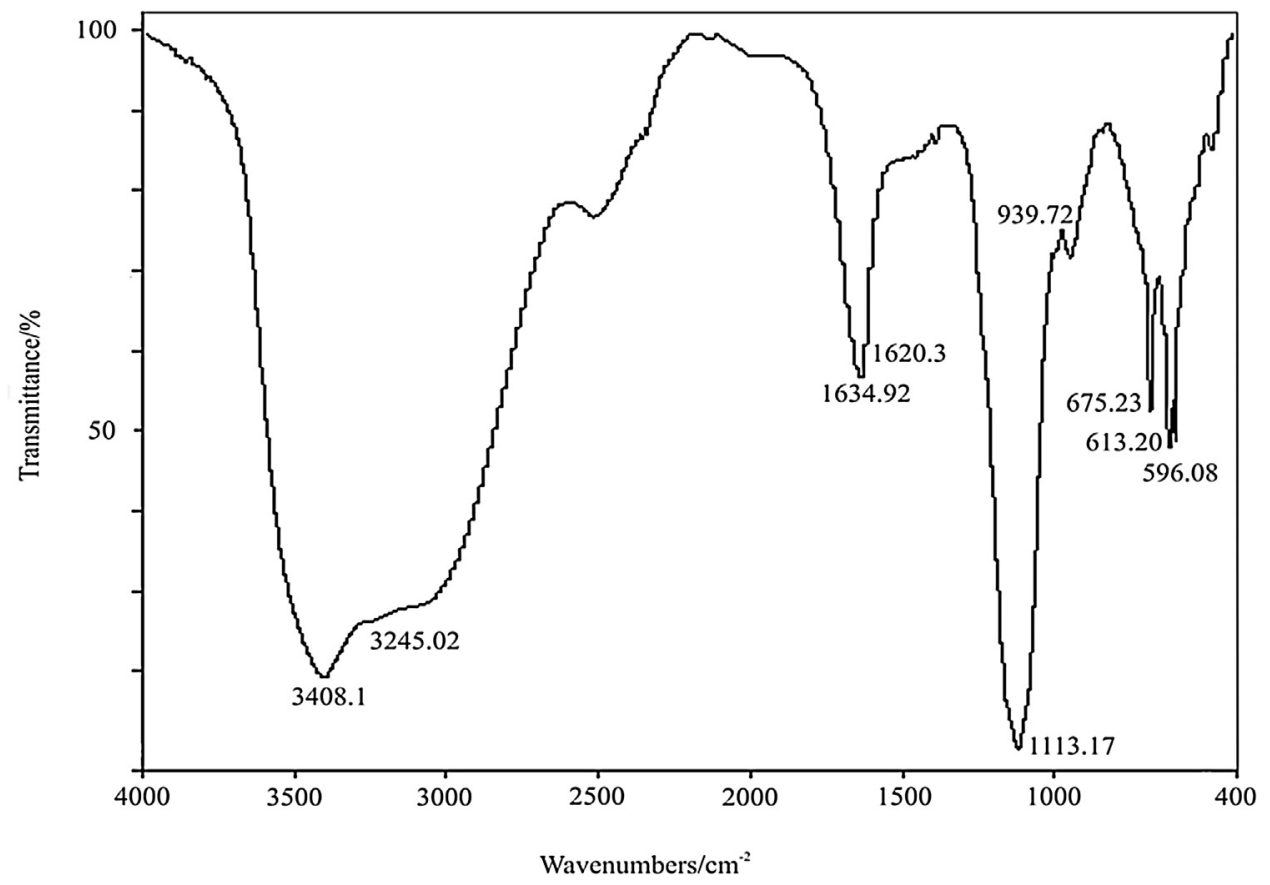

Fig. 3. Infrared spectra of PG $\alpha 21 \mathrm{Ca}$ absorption bands in the range of $400-4000 \mathrm{~cm}^{-1}$. 
$\mathrm{C}-\mathrm{N}$ stretching band at $1116 \mathrm{~cm}^{-1} ; \mathrm{N}-\mathrm{H}$ bending band at $669 \mathrm{~cm}^{-1}$; and $\mathrm{O}-\mathrm{H}$ stretching band at $3415 \mathrm{~cm}^{-1}$.

\subsection{Thermal degradation of PG $\alpha 21 \mathrm{Ca}$}

PGA was analyzed by TGA/DTG and DSC thermoanalytical techniques in synthetic air and $\mathrm{N}_{2}$ atmosphere at a heating rate of $20^{\circ} \mathrm{C} \mathrm{min}^{-1}$ (Fig. 4). The TGA/DTG curves indicated that the sample was thermally stable up to $97.93^{\circ} \mathrm{C}$ and decomposed in three main stages, between $152.4,334.2$ and $801.3^{\circ} \mathrm{C}$. The three well-defined thermal events in both synthetic air and nitrogen atmospheres were clearly represented by successive reactions involving thermal characteristics of calcium sulfate and aluminum sulfate. In the case of PG $\alpha 21 \mathrm{Ca}$, the thermogravimetric analysis revealed a slight mass loss of $0.6192 \mathrm{mg}$, with a calculated residual mass of $89.10 \%$, during the decomposition process. Çilgi and Cetişli [22] stated that the thermal decomposition of aluminum sulfate hydrate occurs in four major stages, all endothermic. The peak temperatures for the dehydration reaction occur in Stage I $\left(51.85-80.85^{\circ} \mathrm{C}\right)$ and II $(80.85$ $\left.184.85^{\circ} \mathrm{C}\right)$. The aluminum sulfate decomposition step begins at $691^{\circ} \mathrm{C}$.

Gypsum showed two peaks in the range of $150-200^{\circ} \mathrm{C}$, representing the stepwise removal of water. At low concentrations, gypsum yielded a single peak at about $150-160^{\circ} \mathrm{C}$. Free water had an endothermic effect at $100^{\circ} \mathrm{C}$. The hexagonal phase exhibited an endothermic peak at about $160-175^{\circ} \mathrm{C}$, the cubic form of gypsum at $300-325^{\circ} \mathrm{C}$ [23]. The DTG curve of PG $\alpha 21 \mathrm{Ca}$ showed welldefined thermal events characteristic of gypsum decomposition at 152.7 and $178.3^{\circ} \mathrm{C}$. The decomposition of gypsum occurs in two stages, with the formation of hemihydrate at around $130^{\circ} \mathrm{C}$ and of anhydrite at around $170^{\circ} \mathrm{C}$.

$\mathrm{CaSO}_{4} \cdot 2 \mathrm{H}_{2} \mathrm{O} \rightarrow \mathrm{CaSO}_{4} \cdot 1 / 2 \mathrm{H}_{2} \mathrm{O}+1.5 \mathrm{H}_{2} \mathrm{O} \rightarrow 2 \mathrm{CaSO}_{4}+\mathrm{H}_{2} \mathrm{O}$

Ho et al. [18] made a thermal analysis of calcium $\gamma$-polyglutamate and found $20 \%$ hydrated water, a dehydration temperature of $110^{\circ} \mathrm{C}$, and a decomposition temperature of $335.7^{\circ} \mathrm{C}$, but did not observe the melting point.

\subsection{Coagulation-flocculation-sedimentation tests}

One of the approaches of this study focused on coagulationflocculation-sedimentation experiments of raw water samples

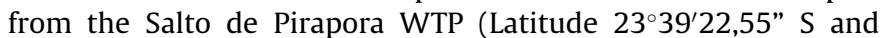
Longitude $47^{\circ} 34^{\prime} 27,66^{\prime \prime}$ W), in the state of São Paulo, Brazil. The raw water analyses were performed no more than $24 \mathrm{~h}$ after collecting the samples. Sampling was carried out in 2015 during rainy and dry periods. A sample was frozen immediately after filtering to determine nitrogen and phosphorus compounds. Filtration was performed using a vacuum pump and hydrophilic membrane filters (Millipore) with $0.45 \mu \mathrm{m}$ pores. Parameters such as alkalinity, anions, cations and trace metals were also analyzed, and are described in Tables 4 and 5. The geology of the municipality of Salto de Pirapora favors mining of limestone rock belonging to the São Roque Group, in the form of limestone lenses, and dolomitic phyllite and calc schist. This lithological substrate, allied to the region's mining operations, leads to substantial calcium carbonate content in the raw water.

The commercial coagulants used in the coagulation-flocculation-sedimentation tests were aluminum sulfate $\left(16 \% \mathrm{Al}_{2} \mathrm{O}_{3}\right)$ and PAC $\left(9.59 \% \mathrm{Al}_{2} \mathrm{O}_{3}\right)$, as well as PG $\alpha 21 \mathrm{Ca}$ imported from Japan. The levels of coagulants were established based on preliminary tests and recommended by the WTP, but the parameters of $\mathrm{pH}$ and temperature of the raw water were not changed. The optimum operating conditions for bioflocculant treatment were determined by the jar test procedure and, in this case, the PG $\alpha 21$ Ca was used directly in its powder form for the jar test.

The experiments were performed on a laboratory scale (jar testing), whose main purpose was to vary the velocity gradient during the simultaneous stirring of six square 2-l acrylic test jars. In these jar test experiments, we applied rapid mixing times of $10 \mathrm{~s}$, an average rapid mixing velocity gradient of $1000 \mathrm{~s}^{-1}$, flocculation time of $30 \mathrm{~min}$, and an average flocculation velocity gradient of $15 \mathrm{~s}^{-1}$. Lastly, we studied the influence of the settling velocity of $1 \mathrm{~cm} \mathrm{~min}{ }^{-1}$ with simultaneous collection of samples from the sampling port located $7 \mathrm{~cm}$ below the $2 \mathrm{~L}$ marking on the six jars.

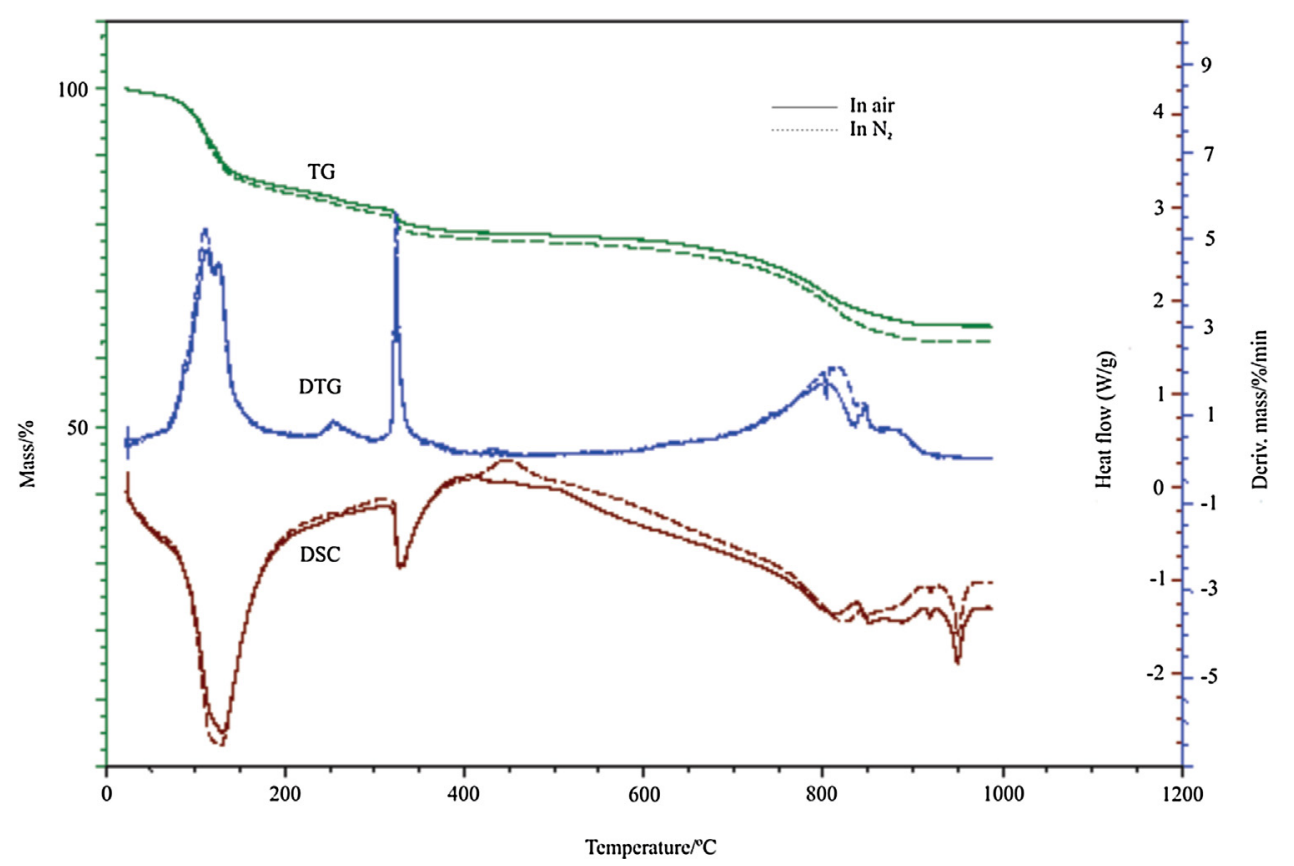

Fig. 4. TG/DTG and DSC curves for $\mathrm{PG} \alpha 21 \mathrm{Ca}$ measured at a heating rate of $20^{\circ} \mathrm{C} \mathrm{min}^{-1}$ (nitrogen and air atmospheres). 
Table 4

Analytical results of raw water from the Salto de Pirapora WTP pertaining to the main dissolved chemical species (cations and anions), in mg $\mathrm{L}^{-1}$.

\begin{tabular}{|c|c|c|c|c|c|c|c|c|c|c|c|c|}
\hline Sample & $\mathrm{Na}^{+}$ & $\mathrm{Ca}^{2+}$ & $\mathrm{K}^{+}$ & $\mathrm{Mg}^{2+}$ & $\mathrm{Al}$ & $\mathrm{Fe}$ & Mn & $\mathrm{Cl}^{-}$ & $\mathrm{HCO}_{3}{ }^{-}$ & $\mathrm{NO}_{3}{ }^{-}$ & $\mathrm{SO}_{4}^{2-}$ & $\mathrm{PO}_{4}{ }^{3-}$ \\
\hline Dry season & 8.56 & 20.11 & 4.62 & 2.43 & 0.19 & 0.23 & LQ & 14.77 & 54.68 & 3.72 & 7.49 & 0.13 \\
\hline Rainy season & 5.63 & 12.95 & 4.54 & 2.70 & 16.29 & 5.77 & LQ & 9.06 & 45.32 & 3.26 & 7.12 & LOQ \\
\hline
\end{tabular}

Note: results below the limit of quantification of the method $\left(\mathrm{LOQ}=0.01 \mathrm{mg} \mathrm{L}^{-1}\right)$.

Table 5

Physicochemical parameters of raw water from the Salto de Pirapora WTP in the dry and rainy seasons.

\begin{tabular}{llll}
\hline Parameters & Unit & Dry & Rainy \\
\hline $\mathrm{pH}$ & - & 7.50 & 6.92 \\
color & $\mathrm{HU}$ & 720 & 750 \\
turbidity & $\mathrm{NTU}$ & 458 & 633 \\
alkalinity & $\mathrm{mg} \mathrm{L}^{-1}$ & 42 & 43 \\
$\mathrm{EC}$ & $\mu \mathrm{S} \mathrm{cm}^{-1}$ & 157.9 & 260.17 \\
$\mathrm{~T}$ & ${ }^{\circ} \mathrm{C}$ & 25 & 24.8 \\
\hline
\end{tabular}

Note: Hu, Hazen units; EC, electrical conductivity; NTU, nephelometric turbidity unit; $\mathrm{T}$, temperature.

After the tests, the residual turbidity and percent removal of apparent color of the best settling results $\left(1 \mathrm{~cm} \mathrm{~min}^{-1}\right)$ were calculated, as illustrated in Figs. 5-7. Fig. 8 shows the results of the tests performed on water collected during the rainy season, and in this case, using only the commercial product with the highest efficiency in the previous phase, i.e., PG $\alpha 21 \mathrm{Ca}$.

Fig. 5 shows the residual turbidity of $90.55 \%$ and the percent removal of apparent color of 9.67 NTU obtained with PAC, while Fig. 6 shows the residual turbidity of $85.49 \%$ and percent removal of apparent color of 12.61 NTU obtained with aluminum sulfate. The best values obtained with PAC were at the level of $90 \mathrm{mg} \mathrm{L}^{-1}$. The use of PAC in place of aluminum sulfate reportedly offers economic and environmental advantages because it significantly reduces neutralizing agents such as hydrated lime and sodium carbonate. PAC also promotes coagulation in any $\mathrm{pH}$ range and can be applied at two to eight times lower levels than aluminum sulfate, generating less sludge, providing better water clarification, and facilitating filtration by reducing the filter cleaning frequency [24,25].

Fig. 7 illustrates the use of PG $\alpha 21 \mathrm{Ca}$ at a level of $80 \mathrm{mg} \mathrm{L}^{-1}$, with removal of apparent color and residual turbidity of $89.74 \%$ and 5.78 NTU, respectively. Note that PG $\alpha 21 \mathrm{Ca}$ was effective even at a low level of $55 \mathrm{mg} \mathrm{L}^{-1}$ (81.24\% and $11.81 \mathrm{NTU}$ ), approaching or even surpassing the results of residual turbidity of the other coagulants applied at higher levels in this study.

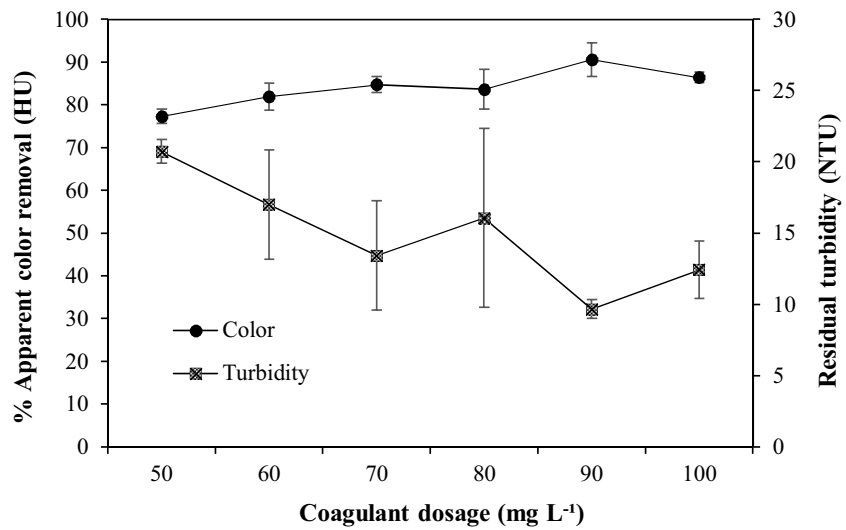

Fig. 5. Residual turbidity and apparent color removal rate of water treated with PAC (Vs $1 \mathrm{~cm} \mathrm{~min}^{-1}$ ) in the dry season.
According to Pan et al. [26], the flocculation efficiency of glutamic acid is dosage-dependent. Research has shown that, in kaolin suspensions, $\gamma$-PGA shows a flocculation rate of $95.8 \%$, in the conditions of $300 \mathrm{mg} \mathrm{L}^{-1}$ of PGA, pH 7, a temperature of $25^{\circ} \mathrm{C}$ and a $350 \mathrm{rpm}$ agitation rate. Carvajal-Zarrabal et al. [11], who studied the use of PGA in the treatment of tequila vinasse, a waste generated in ethanol distilleries, reported that the use of $\gamma$-PGA (250-300 $\mathrm{mg} \mathrm{L}^{-1}$ ) combined with sodium hypochlorite and sand filtration successfully removed about $70 \%$ of turbidity and reduced the chemical oxygen demand (COD) by $79.5 \%$, with the additional benefit of color removal. The authors, who called PG $\alpha 21 \mathrm{Ca}$ a harmless biodegradable biopolymer flocculant, report the effectiveness of the product, due to the high turbidity removal rate even at the natural $\mathrm{pH}$ of the vinasse (3.5), highlighting its remarkable effect in removing turbidity.

Fig. 8 shows variations in residual turbidity of 14.67-1.98 NTU and apparent color removal rates of $86.65-96.95 \%$ at levels of 60 $100 \mathrm{mg} \mathrm{L}^{-1}$. As can be seen, at levels starting from $70 \mathrm{mgL}^{-1}$, turbidity was reduced to below 5 NTU, the maximum value permitted for drinking water in Brazil [27], while a level of $90 \mathrm{mgL}^{-1}$ resulted in residual turbidity of $1.93 \mathrm{NTU}$ (removal of 99.74\%) and apparent color of $96.89 \%$. The results indicate the satisfactory performance of PG $\alpha 21 \mathrm{Ca}$ in the removal of apparent color and residual turbidity in the treatment of raw water in the rainy season, demonstrating flexibility when varying the water quality parameters.

The chemical analysis of the composition of PG $\alpha 21 \mathrm{Ca}$ indicated the presence of aluminum sulfate and $\gamma$-PGA. The former is responsible for agglomerating suspended or colloidal impurities and the latter for forming bonds between the colloids, leading to the formation of denser particles and heavier flakes. According to Huang [28], chemical coagulants such as aluminum salts, iron salts, polyaluminum chloride, polyferric chloride and polyacrylamide are still widely applied in the treatment of drinking water due to their outstanding coagulation performance and low cost [29]. However, these common coagulants still induce several healthrelated and environmental problems. The potential neurotoxic hazard posed by aluminum is generally accepted [30], as is the genetic toxicity of acrylamide monomer [31].

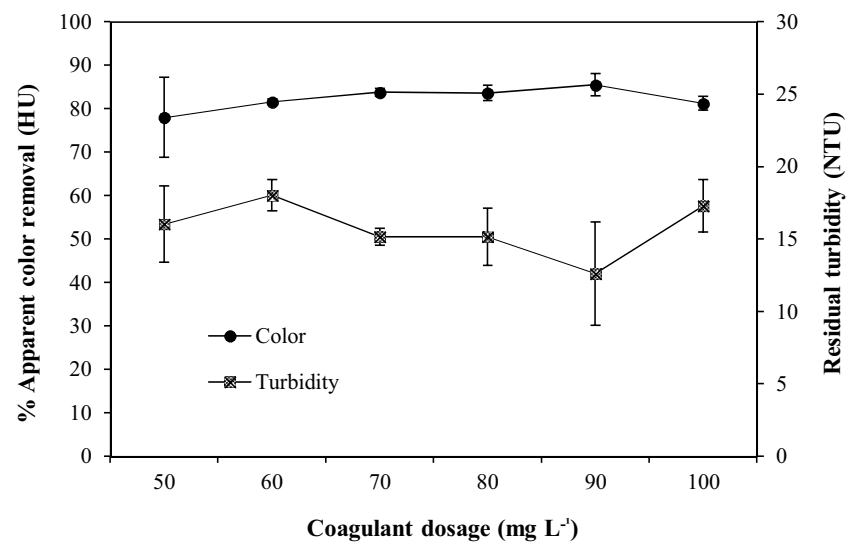

Fig. 6. Residual turbidity and apparent color removal rate of water treated with aluminum sulfate (Vs $1 \mathrm{~cm} \mathrm{~min}^{-1}$ ) in the dry season. 


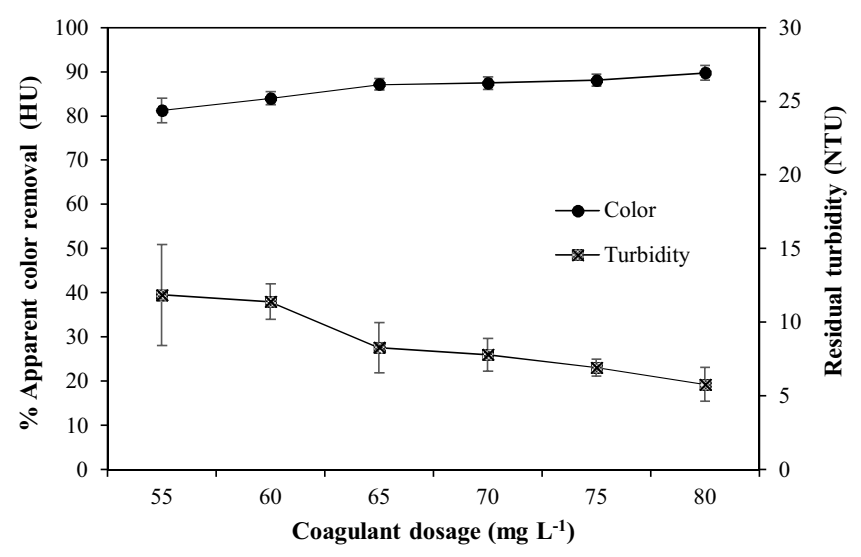

Fig. 7. Residual turbidity and apparent color removal rate of water treated with PG $\alpha 21 \mathrm{Ca}\left(V s \quad 1 \mathrm{~cm} \mathrm{~min}^{-1}\right.$ ) in the dry season.

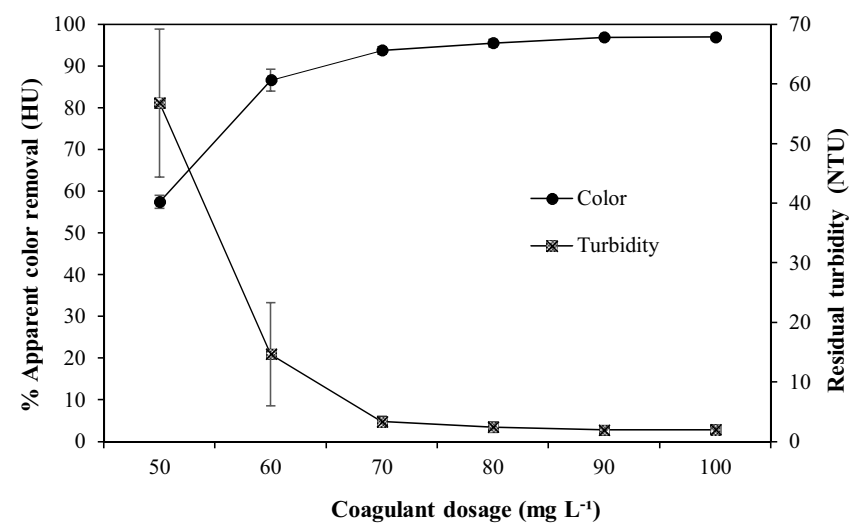

Fig. 8. Residual turbidity and apparent color removal rate of water treated with $\mathrm{PG} \alpha 21 \mathrm{Ca}$ (Vs $1 \mathrm{~cm} \mathrm{~min}^{-1}$ ) in the rainy season.

The excellent performance PG $\alpha 21 \mathrm{Ca}$ in the removal of turbidity and apparent color is associated with the functions of its components, i.e., the inorganic fraction neutralizes colloidal charges owing to the presence of $\mathrm{Ca}^{2+}$ and $\mathrm{Al}^{3+}$ cations [32], and $\gamma$-PGA acts as a chelator, forming bridges between the small particles. Table 1 shows the presence of aluminum in the formulation of PG $\alpha 21 \mathrm{Ca}$. However, the ability to form residual aluminum in water treated with PG $\alpha 21$ Ca can be considered low, since $\gamma$-PGA can bind to multiple metal ions, such as $\mathrm{Al}^{3+}[32]$.

\section{Conclusion}

Conventional water treatment tests were carried out using the jar test with six square beakers $(2 \mathrm{~L})$, which provided velocity gradients in the range of $10-1200 \mathrm{~s}^{-1}$. PAC showed better performance than aluminum sulfate in the removal of apparent color and turbidity from raw water from Salto de Pirapora. However, PG $\alpha 21 \mathrm{Ca}$, whose formulation contains an inorganic portion and another of $y$-PGA, showed better results in the removal of apparent color and turbidity from raw water than the other coagulants, and also caused little change in the water $\mathrm{pH}$ level.

At $90 \mathrm{mg} \mathrm{L}^{-1}$, PAC presented an apparent color removal rate of $90.55 \%$ and residual turbidity of 9.67 . In contrast, at an initial level of $90 \mathrm{mg} \mathrm{L}^{-1}$, aluminum sulfate removed $85.49 \%$ of apparent color while residual turbidity was 12.61 NTU. In the dry season, $80 \mathrm{mg} \mathrm{L}^{-1}$ of PG $21 \mathrm{Ca}$ removed $89.74 \%$ of apparent color and residual turbidity was $5.78 \mathrm{NTU}$. In the rainy season, at $90 \mathrm{mg} \mathrm{L}^{-1}$,
PG $\alpha 21$ Ca removed $96.89 \%$ of apparent color and residual turbidity was 1.93 NTU.

PG $\alpha 21 \mathrm{Ca}$ is basically composed of calcium sulfate (87\%), $\gamma$-polyglutamic acid (5.26\%), and other chemical compounds. The chemical analysis of PG $\alpha 21 \mathrm{Ca}$ indicated that the product is essentially inorganic. In fact, PG $\alpha 21 \mathrm{Ca}$ can be considered a hybrid coagulant that combines aluminum sulfate and $\gamma$-PGA. In this case, we understand that the presence of gypsum and anhydrite as excipients is justified since they facilitate dosing and also contribute to the formation of a water-insoluble compound, because $\gamma$-polyglutamic acid can react with calcium, i.e., the solubility of $\mathrm{CaSO}_{4}$ in water is $2 \mathrm{~g} \mathrm{~L}^{-1}$, thus enabling it to react with $\gamma$-PGA. In addition to containing calcium sulfate as excipient, the formulation of $\mathrm{PG} \alpha 21 \mathrm{Ca}$ includes a conventional coagulant, aluminum sulfate, calcium carbonate as the alkalizing agent, and $\gamma$-polyglutamic acid as an adjuvant compound, i.e., an anionic polymer that is able to form bridges between coagulated particles and thus create larger flakes.

In the process of coagulation-flocculation and separation of solids from the liquid phase by settling, PG $\alpha 21 \mathrm{Ca}$ showed significant results in the removal of apparent color and in the residual turbidity of water samples collected in the dry and rainy seasons, especially with respect to the aluminum sulfate coagulants. However, it should be kept in mind that this product is inorganic and may produce large quantities of raw sludge, which would have to be managed.

\section{Acknowledgements}

This research was financed by the São Paulo Research Foundation - FAPESP (grant 2015/02650-8). The authors thank the Dean of Research of UNESP, as well as FAPESP, for granting science introduction scholarships, which are very helpful in our laboratory routine. We are also indebted to the Salto de Pirapora Water Treatment Plant of SABESP.

\section{References}

[1] L. Rizzo, G. Lofrano, M. Grassi, V. Belgiorno, Pre-treatment of olive mill wasterwater by chitosan coagulation and advanced oxidation processes, Sep. Purif. Technol. 63 (2008) 648-653.

[2] T. Okuda, A.U. Baes, W. Nishijima, M. Okada, Improvement of extraction method of coagulation active components from Moringa oleífera seed, Water Res. 33 (15) (1999) 3373-3378.

[3] W.J. Lukiw, Aluminum and gene transcription in the mammalian central nervous system - implications for Alzheimer's Disease, in: C. Exley (Ed.), Aluminum and Alzheimer's Disease: The Science That Describes the Link, Elsevier Publishers, London, 2001, pp. 147-168.

[4] P. Niquette, M. Frédéric, A. Azzouz, R. Hausler, Impacts of substituting aluminum-based coagulants in drinking water treatment, Water Qual. Res. J. 39 (3) (2004) 303-310.

[5] M.R. Schetinger, C.D. Bonan, V.M. Morsch, D. Bohrer, L.M. Valentim, S.R. Rodrigues, Effects of aluminum sulfate on delta-aminolevulinate dehydratase from kidney, brain, and liver of adult mice, Braz. J. Med. Biol. Res. 32 (6) (1999) 761-766.

[6] Y. Shi, M. Fan, R.C. Brown, S. Sung, J(Hans).V. Leeuwen, Comparison of corrosivity of polymeric sulfate ferric and ferric chloride as coagulants in water treatment, Chem. Eng. Process 43 (2004) 955-964.

[7] D. Zeng, J. Wu, J.F. Kennedy, Application of a chitosan flocculant to water treatment, Carbohydr. Polym. 71 (2008) 135-139.

[8] M. Sellami, Z. Zarai, M. Khadhraoui, Cactus juice as bioflocculant in the coagulation-flocculation process for industrial wastewater treatment: a comparative study with polyacrylamide, Water Sci. Technol. 70 (7) (2014) 1175-1181.

[9] V. Campos, J. Dweck, C.A.O. Nascimento, C.M. Tcacenco, Thermal stability of ionene polymers, J. Therm. Anal. Calorim. 112 (2013) 1221-1229.

[10] V. Campos, C.M. Tacenco, Synthesis of polycationic bentonite-ionene complexes and their benzene adsorption capacities, Polímeros 25 (2015) 146-153.

[11] O. Carvajal-Zarrabal, C. Nolasco-Hipólito, D.M. Barradas-Dermitz, P.M. Hayward-Jones, M.G. Aguilar-Uscanga, K. Bujang, Treatment of vinasse from tequila production using polyglutamic acid, J. Environ. Manage. 95 (2012) 66-70. 
[12] J.A.A. Arpal, Compuestos estequiométricos del ácido poli(y-glutâmico) com tensoactivos catiónicos, Dissertação, ETSEIB (2004).

[13] M. Kunioka, Biodegradable water absorbent synthesized from bacterial poly (amino acid)s, Macromol. Biosci. 4 (2004) 324-329.

[14] M. Taniguchi, K. Kato, A. Shimauchi, X. Ping, K.I. Fujita, T. Tanaka, Y. Tarui, E. Hirasawa, Physicochemical properties of cross-linked poly-c-glutamic acid and its flocculating activity against kaolin suspension, J. Biosci. Bioeng. 99 (2) (2005) 130-135.

[15] B.C. Capelette, Emprego da quitosana como coagulante no tratamento de água contend Microcystis aeruginosa-Avaliação de eficiência e formação de trihalometanos, Dissertação, Universidade de Brasília, Brasília, 2011.

[16] I.L. Shih, Y.T. Van, The production of poly-(y-glutamic acid) from microorganisms and its various applications, Bioresour. Technol. 79 (3) (2001) 207-225.

[17] E.P. Barrett, L.G. Joyner, P.P. Halenda, The determination of pore volume and area distribuitions in porous substances. I. Computations from nitrogen isothermas, J. Am. Chem. Soc. 73 (1951) 373-380.

[18] G.H. Ho, T.I. Ho, K.H. Hsieh, Y.C. Su, P.Y. Line, J. Yang, K.H. Yang, S.C. Yang, yPolyglutamic acid produced by Bacillus subtilis (natto): structural characteristics, chemical properties and biological functionalities, J. Chin. Chem. Soc. Taip. 53 (2006) 1363-1384.

[19] J.T. Kloprogge, R.L. Frost, Raman microscopy at $77 \mathrm{~K}$ of natural gypsum $\mathrm{CaSO}_{4} \cdot 2 \mathrm{H}_{2}$ O, J. Mater. Sci. Lett. 19 (2000) 229-231.

[20] J.P. Soares, Estudo microestrutural do gesso-alfa produzido pelo processo hidrotérmico e calcinação a seco e sua influência nas propriedades mecânicas pós hidratação, Dissertação, Universidade Federal de Pernambuco, Recife, 2005.

[21] K.P. Mandal, T.K. Mandal, Anion water in gypsum $\left(\mathrm{CaSO}_{4} \cdot 2 \mathrm{H}_{2} \mathrm{O}\right)$ and hemihydrate $\left(\mathrm{CaSO}_{4} \cdot 1 / 2 \mathrm{H}_{2} \mathrm{O}\right)$, Cem. Concr. Res. 32 (2) (2002) 313-316.

[22] G.K. Çılgı, H. Cetişli, Thermal decomposition kinetics of aluminum sulfate hydrate, J. Therm. Anal. Calorim. 98 (2009) 855-861.
[23] V.S. Ramachandran, M.R. Paroli, J.J. Beaudoin, A.H. Delgado, Gypsum and Gypsum Products in Handbook of Thermal Analysis of Construction Materials, Noyes Publications, Norwich, 2001.

[24] M. Furtado, Coagulantes modificados e mais eficazes reforçam o poder da clarificação. http://www.quimica.com.br/agua-coagulantes-modificados-emais-eficazes-reforcam-o-poder-da-clarificacao/, 2009 (accessed 02.07.2016).

[25] A. Matilainen, M. Vepsalainen, M. Sillanpaa, Natural organic matter removal by coagulation during drinking water treatment, Adv. Colloid Interface Sci. 159 (2010) 189-197.

[26] Y. Pan, B. Shi, Y. Shang, Research on flocculation property of bioflocculant PG. a21 Ca, Modern Appl. Sci. 3 (6) (2009) 106-112.

[27] BRASIL. Ministério da Saúde. Portaria 2.914, de 12 de dezembro de 2011. Dispõe sobre os procedimentos de controle e vigilância da qualidade da água para o consumo humano e seu padrão de potabilidade. Brasília: Ministério da Saúde, 2011 (accessed 02.07.16).

[28] X. Huang, S. Sun, B. Gao, Q. Yue, Y. Wang, Q. Li, Coagulation behavior and floc properties of compound bioflocculant-polyaluminum chloride dualcoagulants and polymeric aluminum in low temperature surface water treatment, J. Environ. Sci. 30 (2015) 215-222.

[29] Z. Li, S. Zhong, H.Y. Lei, R.W. Chen, Q. Yu, H.L. Li, Production of a novel bioflocculant by Bacillus licheniformis X14 and its application to low temperature drinking water treatment, Bioresour. Technol. 100 (14) (2009) 3650-3656.

[30] S.C. Bondy, The neurotoxicity of environmental aluminum is still an issue, Neurotoxicology 31 (5) (2010) 575-581.

[31] K.L. Dearfield, G.R. Douglas, U.H. Ehling, M.M. Moore, G.A. Sega, D.J. Brusick, Acrylamide: a review of its genotoxicity and an assessment of heritable genetic risk, Mutat. Res. Fund. Mol. Mech. Mutagen 330 (1995) 71-99.

[32] I. Bajaj, R. Singhal, Poly (glutamic acid)-an emerging biopolymer of commercial interest, Bioresour. Technol. 102 (2011) 5551-5561. 